\title{
INFLUÊNCIA DA LEVODOPA SOBRE A FASE ORAL DA DEGLUTIÇÃO EM PACIENTES COM DOENÇA DE PARKINSON
}

\author{
Influence of levodopa on the oral phase of swallowing \\ in patients with Parkinson's disease
}

\author{
Renata Mancopes ${ }^{(1)}$, Angela Ruviaro Busanello-Stella ${ }^{(2)}$, Leila Susana Finger ${ }^{(3)}$, \\ Aline Prade $\mathrm{Neu}^{(4)}$, Andrielle de Bitencourt Pacheco(5), Mayde Seadi Torriani( ${ }^{(6)}$
}

\begin{abstract}
The purpose of this study is to conduct a literature review in order to verify the possible influence of Levodopa on the oral phase of deglutition in individuals with Parkinson disease. The survey was conducted in journals indexed in Science Direct, Capes periodicals, LILACS, SciELO, MedLine and Scopus, as well as in books. For this survey, the terms disfagia/dysphagia/disfagia, medicamentos/ drugs/las drogas, levodopa, Parkinson/Parkinson disease/ enfermedad de Parkinson and swallowing disorders were used. It was possible to identify 16 international and 25 national scientific articles. After reading every identified papers, 32 were selected in addiction to four books and one abstract published in scientific conference proceedings were used. For such selection, the inclusion criteria were the papers which considered the impairments caused by Parkinson's disease, especially during the oral phase of swallowing, as well as the effects of levodopa about it. As exclusion criteria, the drug influence during pharyngeal phase was considered, because it usually seems to have higher effect during oral phase. There is disagreement in the literature surveyed considering Levodopa possible effects in deglutition. When these effects occur, they generally affect the oral phase of this function, since difficulties already present in Parkinson Disease carriers are maximized by the xerostomia due to the administration of this drug. Considering the vast range of results found in the studies surveyed, developing controlled studies for a detailed elucidation of Levodopa effects in deglutition becomes necessary.
\end{abstract}

KEYWORDS: Deglutition Disorders; Drug Use; Levodopa; Parkinson Disease

(1) Speech Pathology; Associate professor of the Universidade Federal de Santa Maria - UFSM, Santa Maria, RS, Brazil; PhD in Linguistics by the Universidade Federal de Santa Catarina.

(2) Speech Pathology; PhD student of the Post-graduation program in Human Comunication Disorders of the Universidade Federal de Santa Maria - UFSM, Santa Maria, RS, Brazil.

(3) Speech Pathology; PhD student of the Post-graduation program in Human Comunication Disorders of the Universidade Federal de Santa Maria - UFSM, Santa Maria, RS, Brazil.

(4) Speech Pathology; Master student of the Post-graduation program in Human Communication Disorders of the Universidade Federal de Santa Maria - UFSM, Santa Maria, RS, Brazil.

(5) Speech Pathology; Master student of the Post-graduation program in Human Communication Disorders of the Universidade Federal de Santa Maria - UFSM, Santa Maria, RS, Brazil.

\section{INTRODUCTION}

Parkinson's disease (PD) is characterized by being a progressive and degenerative disease ${ }^{1}$ that affects approximately from 1 to $2 \%$ of the population over 65 years of age ${ }^{2}$. Currently, its aetiology is not fully known, but there is a hypothesis that the gradual loss of neurons in the substantia nigra of the midbrain is caused by possible genetic and environmental factors and by the aging itself ${ }^{3}$.

(6) Pharmaceutical, Hospital de Clínicas de Porto Alegre - RS, Porto Alegre, Rio Grande do Sul, Brazil; Master in Clinical Medicine by the Post-graduation program of the Faculdade de Medicina da UFRGS.

Conflict of interest: non-existent 
Manifestations such as tremors at rest, muscle rigidity, bradykinesia, hypokinesia, changes in posture, in balance and voice changes are some of the signs and symptoms of this disease ${ }^{4}$. Difficulties in the functions of swallowing and breathing are also part of the pathophysiology of this disease and require special attention because they increase the possibility of pulmonary aspiration, pneumonia, and thus interfere with the survival and quality of patients' life ${ }^{5}$.

The medical treatment of PD is intended to minimize these symptoms, which is usually done by means of drugs with dopamine base. Drugs in this neurotransmitter are intended to stimulate the dopaminergic receptors located in the postsynaptic neurons ${ }^{6}$. These medications are effective, especially in the more general symptoms of the disease and in improving the quality of life of the subject. However, they present potential side effects that may limit or decrease the efficiency of essential functions to life, such as swallowing.

For the speech pathology, a trained professional in the performance of swallowing difficulties, the pharmacological knowledge becomes necessary. This is because the evaluation, prognosis, conduct and therapeutic evolution will possess basement and deeper study. Furthermore, often, the administered drugs may enhance already existing dysfunctions as well as interfere in the process of speech rehabilitation? ${ }^{7}$.

The impact of the drugs on the physiology of swallowing has been frequently reported in the literature, especially being distinguished symptoms such as decreased level of general consciousness, decreased sensitivity and xerostomia ${ }^{8}$.

From the interface between the drugs for PD and changes in the physiological process of swallowing, the present study was aimed to make bibliographic search to verify the possible influence of the Levodopa on the oral phase of the swallowing in patients with Parkinson's disease.

\section{METHOD}

This study was conducted through a literature review, from which it was sought to build a theoretical framework on the possible influence of the Levodopa on the oral phase of swallowing in patients with Parkinson's disease. It was performed a search of articles published in different databases SCIENCE DIRECT, CAPES journals, MEDLINE, SciELO, LILACS, SCOPUS. The year of publication of the article was not considered a criterion selection due to the scarcity of publications on the topic. To perform the research there were used the following terms: dysphagia, medication, levodopa, Parkinson, dysphagia, drugs, swallowing disorders, Parkinson's disease, disphagia, drugs and Parkinson's disease.

There were identified 16 international and 25 national articles. After this procedure, it was performed the reading of all the identified articles. As inclusion criteria of articles in this review, there were used those that consider the impairment caused by Parkinson's disease, especially in the oral phase of swallowing, as well as the effects of the levodopa on the same. Now, the influence of levodopa in the pharyngeal phase of swallowing was an exclusion criterion, because this drug usually seems to have a greater effect on the oral phase, since the difficulties that the bearer of Parkinson's disease already presents, are maximized by the xerostomia resulting from the administration of levodopa. Of this total of 41 found articles, there were selected 32 . There were also used four books and a summary of the proceedings of Congress due to the relevance related to the studied topic and its importance for the scientific area.

\section{LITERATURE REVIEW}

\section{Parkinson's disease}

$\mathrm{PD}$ is a clinically common disease, having mainly motor manifestations in the affected individuals, being its diagnosis based on the presence of resting tremor, rigidity, bradykinesia, and in the advanced stage, alteration of postural reflexes ${ }^{9}$. Among these symptoms, the individual with the disease can still experiencing pain, fatigue, depression, cognitive and sexual disorders ${ }^{10}$ as well as olfaction changes ${ }^{11}$.

The progressive nature causes that the disease evolution generates secondary complications arising from the primary physical signs and symptoms. This can lead to mental/emotional, social and economical impairment to the patient, making it often unable to perform activities of daily living ${ }^{12}$. This distancing of the subject from his daily routine and from his previous capacities contributes to decreased quality of life ${ }^{13}$.

The involvement of the axial musculature involves, in different degrees, the impairment of speech and voice (dysarthrophonia) in addition to the impairment of the physiological process of swallowing (disphagia). Disphagia has high prevalence in the PD according to the literature, resulting from difficulties in the tongue movements and other structures of the stomatognathic system and especially of the incoordination of them. Apart from that, commonly, patients with PD also present dysphagia with impairment of the oesophageal phase, due to the decrease of the peristalsis process $^{14}$. 
However, the characteristics of the disphagia in the PD are not fully understood. It is known that occurs mainly in the oral leakage of saliva ${ }^{15}$ and sialorrhea ${ }^{14}$. But disphagia as a symptom and sign of PD, is characterized by affect all phases of swallowing ${ }^{16}$, especially the oral phase. In this disease, aspiration pneumonia does not happen often, and the aspiration itself may occur without the presence of disphagia. This is because the respiratory impairment in these subjects is significant and often causes death in this population ${ }^{17}$.

\section{Treatment of Parkinson Disease}

After the diagnosis of PD, it should be analysed the patient's conditions and the impact of the disease on daily activities, aiming the beginning of the early treatment ${ }^{18}$.

The elective treatment is usually done by the physician in conjunction with the patient and/or their families, and will go through several phases, depending on the patient's impairment and disease progression. Its main focus is maintaining the quality of life $^{18}$ and, therefore, is important, in addition to drug treatment, the multi and interdisciplinary intervention (phonoaudiology, physiotherapy, occupational therapy, nutrition, among others) ${ }^{7}$.

The most widely used drugs in the treatment of PD are: anticholinergics to minimize tremor $^{19}$, tricyclic antidepressants, and selective inhibitors of serotonin reuptake, antipsychotics and anticonvulsants for depression disorders and to prevent convulsions $^{20}$ and the dopaminergic to directly stimulate the dopamine receptors ${ }^{21}$. Within this latter group, the levodopa has been highlighted in the reduction of parkinsonian symptoms ${ }^{7}$.

\section{Possible implications of the Levodopa in the speech therapy aspects}

The most common drug treatment for $\mathrm{PD}$ is the use of Levodopa, for being the most effective single agent in treating this disease. According to the literature ${ }^{22}$, it is possible that at the beginning of the treatment, $80 \%$ of patients show improvement in most of the symptoms.

This drug enables the dopaminergic replacement, being a precursor of the dopamine. Levodopa is absorbed in the duodenum, being transported through the bloodstream to the brain, turning it into dopamine by the action of the dopa decarboxylase enzyme. Through this absorption process, it corrects the biochemical deficit caused by the disease, improving the global motor symptoms ${ }^{23}$, while reducing the mortality rate of these patients ${ }^{22}$.

Dopaminergic drugs have proven to be effective to virtually improve all the measures of pulmonary function. However, there are little evidences about the direct effects of levodopa in the swallowing ${ }^{24}$. Most of the performed studies have small samples and show slight improvement in disphagia in a portion of participants, with a decline of this function in other studies $^{5,25}$. Another study ${ }^{26}$ also suggests that the abnormalities of swallowing in PD do not seem to be exclusively related to dopamine deficiency.

It is also taken into consideration by some authors, the fact that the administration of Levodopa is a potential to increase the production of free radicals, resulting from the metabolism of dopamine, contributing to the degenerative process, since they affect the neurons of the substantia nigra ${ }^{21}$. This would help in aggravation of the disease rather than in its improvement, affecting the patient as a whole and inevitably the functions of the SE.

Many studies are divided on the benefit, harm or indifference of the administration of the Levodopa before swallowing. One study compared the effect of maximal doses of Levodopa tolerated orally (1 to 6.6 grams per day) with doses of placebo in 18 patients with idiopathic parkinsionism through the side cineradiography. There was no statistical difference between the pharyngeal transit times (main objective of the study) during the administration of levodopa and of the placebo ${ }^{24}$, which agrees with the lack of significance found by Bushmann et al. (1989) ${ }^{27}$.

The oropharyngeal ability of swallowing in the PD was examined in 19 patients before and after administration of $200 \mathrm{mg}$ of Levodopa combined with benserazide $(50 \mathrm{mg})$. The authors ${ }^{28}$ concluded, contrary to previous studies, that more than half of the patients experienced improvement of the swallowing function after the treatment with Levodopa, possibly due to the reduction of bradykinesia and rigidity of the tongue.

These results also go against the findings of another study ${ }^{5}$, in which the usual dose of levodopa was related to the coordination of swallowing and breathing in patients with PD. The authors concluded that the efficiency of swallowing seems to have been reduced with the administration of Levodopa, but no association was found between the Levodopa and the coordination of swallowing and breathing, and laryngeal penetration or tracheal aspiration.

Comparing the effect of the levodopa in the PD and in the parkinsonism induced by drugs, studies showed ${ }^{29,30}$ that, although Levodopa can improve swallowing in both cases, these entities cannot be assimilated. In the long term, the forecasts are different as well as the pathophysiology. The degenerative process in PD includes not only the dopaminergic system but also the noradrenergic, serotonergic and cholinergic, among others. Therefore, swallowing of parkinsonism induced by 
drugs may not be comparable in all aspects with the idiopathic Parkinson's disease.

Every drug, including the Levodopa, has specific aims to prevent, alleviate and cure certain diseases, but can cause side effects to the patients ${ }^{30}$. Among the main adverse effects of this drug may be: nausea, vomiting, diarrhoea, loss of appetite, weight loss, dysgeusia, odynophagia, dyskinesia, amnesia, diplopia and xerostomia ${ }^{8,21}$.

The xerostomia, a odinophagia and dyskinesia of the tongue and of the lips may negatively influence in the physiological process of swallowing. Regarding the involuntary movements ${ }^{31}$, specifically, drug interactions, in particular of the Levodopa, can trigger them. They are characterized for being abnormal, and mainly for affecting the extremities (among them, the jaw) showing motor adjustments of the choreiform type, dystonia, athetosis, tics and myoclonus ${ }^{32}$.

Patients treated with Levodopa may develop motor instability and/or dyskinesia after some years of drug administration. Abnormal involuntary movements manifested by patients with dyskinesia may contribute to the establishment of swallowing abnormalities in the PD ${ }^{17}$.

Xerostomia is described as a subjective sensation of dry mouth that may be consequent of the decrease or cessation of the salivary glands function $^{33}$. It presents as main causes: health status, side effects of radiation on cancer of the head and neck and side effect of several drugs ${ }^{8,34,35}$. Besides these causes, the dysfunctions in the salivary centres may also be related to changes in function of the gland itself, and diseases such as PD ${ }^{36}$.

Among the drugs that can cause xerostomia the anti-parkinsonian, antidepressants, antipsychotics, antihistamines, analgesics, tranquillizers, antihypertensives ${ }^{8}$, anxiolytics, anticholinergics, and anticonvulsants ${ }^{35}$ stood out.

In addition to moisten the tissues of the oral cavity, saliva, with its lubricating property, helps in the formation and swallowing of the bolus. Thus, the xerostomia causes significant effects on chewing, swallowing and taste, minimizing the effectiveness of the oral phase of this function ${ }^{8}$, compromising the nutritional status of the individual ${ }^{36}$. Therefore, the main phase of swallowing affected in the PD, and that is most likely to be influenced by Levodopa is the oral one ${ }^{5}$.

Individuals with PD often have complaints of disphagia in $50 \%$ of the cases. This percentage passes to approximately $90 \%$ when swallowing is evaluated by means of videofluoroscopy ${ }^{37}$. The changes usually appear in all phases of swallowing. At the oral phase, the difficulty of formation of the bolus, the tremors and dyskinesias of the tongue are characteristic of the $\mathrm{PD}^{26,37}$, and when associated with xerostomia caused by Levodopa further undermine this phase of swallowing.

It is evident that some studies show the improvement that the Levodopa produces, in other cases, there may be no influence whatsoever, and in some cases this drug may adversely affect in swallowing. However, in view of the effectiveness for the control of the overall clinical picture, this drug will continue to be prescribed, and patients will need a more careful attention on the aspect of swallowing and of eventual phonoaudiological complications.

\section{CONCLUSION}

There is disagreement in the literature about the potential effects of Levodopa in the swallowing. When these occur, usually affect the oral phase of this function, since the difficulties which the carrier of DP already presents are maximized by the xerostomia resulting from the administration of this drug.

Due to the use of different methodologies, small number of individuals in studies, as well as the consequent diversity of the found results, it is necessary to perform controlled studies to a more detailed elucidation of the effects of Levodopa in the swallowing. 


\section{RESUMO}

Este estudo objetiva realizar levantamento bibliográfico para verificar a possível influência da Levodopa sobre a fase oral da deglutição de indivíduos com Doença de Parkinson. Foi realizado levantamento bibliográfico em periódicos indexados no Science Direct, periódicos Capes, LILACS, SciELO, MedLine e Scopus e livros. Para busca foram utilizados os termos disfagia, medicamentos, levodopa, Parkinson, dysphagia, drugs, swallowing disorders, Parkinson's disease, disfagia, las drogas e enfermedad de parkinson. Foram identificados 16 artigos internacionais e 25 nacionais, após a leitura de todos os artigos identificados foram selecionados 32, utilizaram-se ainda quatro livros e um resumo de anais de congresso. Para tal seleção utilizou-se como critério de inclusão aqueles artigos que considerassem o comprometimento causado pela Doença de Parkinson, especialmente na fase oral da deglutição, bem como os efeitos da levodopa sobre a mesma, e como critério de exclusão a influência do fármaco na fase faríngea, pois geralmente ele parece ter maior efeito na fase oral. Existe discordância na literatura quanto aos possíveis efeitos da Levodopa na deglutição. Quando estes ocorrem, geralmente afetam a fase oral desta função, uma vez que as dificuldades que o portador da Doença de Parkinson já apresenta são maximizadas pela xerostomia decorrente da administração deste fármaco. Em virtude da grande diversidade dos resultados dos estudos encontrados, faz-se necessária a realização de estudos controlados para uma elucidação mais detalhada dos efeitos da Levodopa na deglutição.

DESCRITORES: Transtornos de Deglutição; Uso de Medicamentos; Levodopa; Doença de Parkinson

\section{REFERENCES}

1. Goulart F, Teixeira-Salmela LF, Barbosa CM, Silva CM. O impacto de um programa de atividade física na qualidade de vida de pacientes parkinsonianos. In: Anais do Congresso Brasileiro e do III Congresso Internacional de Psicologia do Esporte; 2003 set 4-6; Rio de Janeiro, Brasil; 2003; p. 19.

2. Ribeiro EM, Dantas CCB, Medeiros ACC, Arruda AP, Carvalhp MDF. [internet]. As bases genéticas da doença de Parkinson. [citado 2004]. Acesso em: 12 de junho de 2011. Disponível em: http://www.moreirajr.com.br/ revistas.asp?id_materia $=2666 \&$ fase=imprime.

3. Ferraz HB. Tratamento da Doença de Parkinson. Rev Neurociências. 1999;7(1):6-12.

4. Guttman M, Kish SJ, Furukawa Y. Current concepts in the diagnosis and management of Parkinson's disease. CMAJ. 2003;168(3):293-301.

5. Lim A, Leow L, Huckabee ML, Frampton C, Anderson T. A pilot study of respiration and swallowing integration in Parkinson's disease: "on" and "off" levodopa. Dysphagia. 2008;23:76-81.

6. Jankovic J, Marsden CD. Therapeutic strategies in Parkinson's disease. In: Jankovic J, Tolosa E. Parkinson's disease and movement disorders. Williams \& Wilkins: Baltimore; 1998:191-220.

7. Silva, AP etal. A farmacolovigilância na reabilitação de pacientes com doenças neurológicas. O mundo da saúde. 2008;32(2):229-37.
8. Gallagher L, Naidoo P. Prescription drugs and their effects on swallowing. Dysphagia. 2010;19:98-102. 9. Melo LM, Barbosa ER, Caramelli P. Declínio cognitivo e demência associados à doença de Parkinson: características clínicas e tratamento. Rev Psiq Clín. 2007;34(4):176-83.

10. Camargos ACR, Copio FCQ, Sousa TRRE, Goulart F. O impacto da doença de Parkinson na qualidade de vida: uma revisão de literatura. Rev Bras Fisioter. 2004;8(3):267-72.

11. Quagliato LB, Viana MA, Quagliato EMAB, Simis S. Alterações do olfato na doença de Parkinson. Arq Neuropsiquiatr. 2007;65(3-A):647-65.

12. Karlsen KH, Tandberg E, Arsland D, Larsen J. Health related quality of life in Parkinson's disease: a prospective longitudinal study. J Neurol Neurosurg Psychiatry. 2000;69(5):584-9.

13. Kuopio AM, Marttila RJ, Helenius H, Toivonen M, Rinne UK. The quality of life in Parkinson's disease. Mov Disord. 2000;15(2):216-23.

14. Nicaretta DH, Pereira JS, Pimentel MLV. Distúrbios autonômicos na doença de Parkinson. Rev Ass Med Brasil. 1998;44(2):120-2.

15. Ferraz HB, Borges V. [internet]. Como diagnosticar e tratar - Doença de Parkinson Moreira JR. [citado em junho de 2011]. Disponível em: http://www.moreirajr.com.br/ revistas.asp?fase $=$ r003\&id_materia $=1870$.

16. Bigal A, Hárumi D, Luz M, Luccia G, Bilton T. Disfagia do idoso: estudo videofluoroscópico de 
idosos com e sem doença de Parkinson. Distúrb. Comum. 2007;19(2):213-23.

17. Monte FS, Silva-Júnior FP, Braga-Neto $P$, Nobre e Souza MÂ., Sales de Bruin VM. Swallowing abnormalities and dyskinesia in Parkinson's disease. Movement Disorders. 2005;20:457-62.

18. Jankovic J, Marsden CD. Therapeutic strategies in Parkinson's disease. In Jankovic J, Tolosa E. Parkinson's disease and movement disorders. Baltimore: William \& Wilkins; 1993. p115-44.

19. Cardoso F. Tratamento da Doença de Parkinson. Arq Neuropsiquiatr. 1995;53(1):1-10.

20. Zesiewicz TA, Helal M, Hauser RA. Sildenafil Citrate (Viagra) for the treatment of erectile dysfunction in men with Parkinson's disease. Mov Disord 2000;15:305-8.

21. Barbosa ER, Sallem FAS. Agonistas dopaminérgicos. Rev. Bras. Neurol. 2005; 41(2):12-21.

22. Rodrigues M, Campos LC. Estratégia para o tratamento com levodopa na doença de Parkinson. Revista Analytica. 2006;(23):44-51.

23. Azevedo LL, Cardoso F. Ação da levodopa e sua influência na voz e na fala de indivíduos com Doença de Parkinson. Rev Soc Bras Fonoaudiol. 2009;14(1):136-41.

24. Calne DB, Shaw DG, Spiers AS, Stern GM. Swallowing in Parkinsonism. $\mathrm{Br} \mathrm{J}$ Radiol. 1970;43:456-7.

25. Baijens LWJ, Speyer R. Effects of therapy for dysphagia in Parkinson's Disease: systematic review. Dysphagia. 2009;24:91-102.

26. Hunter PC, Crameri J, Austin S, Woodward MC, Hughes AJ. Response of parkinsonian swallowing dysfunction to dopaminergic stimulation. J Neurol Neurosurg Psychiatry. 1997;63:579-83.
27. Bushmann M, Dobmeyer SM, Leeker L, Perlmutter JS. Swallowing abnormalities and their response to treatment in Parkinson's disease. Neurology. 1989; 39:1309-14.

28. Fuh JL, Lee RC, Wang SJ, Lin CH, Wang PN, Chiang JH, et al. Swallowing difficulty in Parkinson's disease. Clin Neurol Neurosurg. 1997;99:106-12.

29. Nilson $\mathrm{H}$. Further comments on swallowing in Parkinson's Disease. Dysphagia. 1997;12:98-9.

30. Figueras A, Napchan BM, Mendes GB. Farmacovigilância: ação na reação. São Paulo: Centro de Vigilância Sanitária; 2002.

31. Rocha MSG, Andrade LAF, Ferraz BF, Borges V. Discinesias induzidas por levodopa em 176 pacientes com Doença de Parkinson. Arq Neuropsiquiat. 1995;53(4):737-42.

32. Tolosa E, Alom J, Marti MJ. Drug induced dyskinesias. In Jankovic J, Tolosa E Parkinson's disease and movement disorders. Baltimore: Williams \& Wilkins; 1993. p.375-97.

33. Feio M, Sapeta P. Xerostomia em cuidados paliativos. Acta Med Port. 2005;18:459-66.

34. Thomson WM, Chalmers JM, Spencer AJ, Slade GD. A longitudinal study of medication exposure and xerostomia among older people. Gerodontology. 2006;23:205-13.

35. Rosa LB, Zuccolotto MCC, Bataglion C, Coronatto EAS. Odontogeriatria: a saúde bucal na terceira idade. RFO. 2008;13(2):82-6.

36. Pupo D, Bussoloti IF, Liquidato BM, Korn GP. Proposta de um método prático de sialometria. Rev Bras de Otorrinolagingol. 2002;68(2):219-22.

37. Edwards LL, Quigley EMM, Pfeiffer RF. Gastrointestinal dysfunction in Parkinson's disease: frequency and pathophysiology. Neurology 1992;42:726-32.
http://dx.doi.org/10.1590/S1516-18462013005000023

Received on: September 21, 2011

Accepted on: April 24, 2012

Mailing adress:

Andrielle de Bitencourt Pacheco

Rua Visconde de Pelotas, no 505, apto. 208 -

Bairro Rosário

Santa Maria, RS

CEP: 97010-440

E-mail: andrielle.pacheco@gmail.com 